\title{
CONTENT BASED IMAGE RETRIEVAL BUSANA MUSLIMAH MENGGUNAKAN FITUR KOMBINASI PHOG DAN DCD
}

\author{
Cut Mutia, Muhammad Akmal \\ Program Studi Teknik Informatika, Universitas Jabal Ghafur \\ Jl. Gle Gapui - Sigli, Kabupaten Pidie, Aceh \\ cutmeuthia88@gmail.com, m.akmalmuhammadegmail.com
}

\begin{abstract}
The development of Muslim clothing has increased significantly, especially in Indonesia, where the majority of the population is Muslim. Designers have appeared with a variety of fashion styles that attract consumers, especially young consumers. Technological developments have also influenced the way designers promote and sell their work by utilizing online commerce. So that consumers can search and find various models and colors of clothing that interest them. In this study, the search for Muslim clothing was carried out using the visual content of images or also known as features. The features used in this study are a combination of color and shape features, because shape and color are an attraction for consumers in choosing clothes. Search using image content as a query is known as CBIR. This study applies the PHOG as a shape feature extraction method and the DCD for the extraction of color features. The dataset used is 180 images of Muslim clothing. The performance of CBIR Muslim clothing using a combination of PHOG and DCD features is measured with recall, precision, and f-measure parameters. The results of the performance measurement show that the combination of PHOG and DCD features is better applied to blouse pants clothing. The highest scores were obtained from the red clothing group of $68 \%(\mathrm{P}), 22.2 \%$, and $33.3 \%(\mathrm{~F})$. Then followed by a group of robes, and outerwear.
\end{abstract}

Keywords - CBIR, PHOG, DCD, Feature and Clothing.

\begin{abstract}
Abstrak - Busana muslimah memiliki bentuk dan warna yang beragam dan menarik minat konsumen, banyak situs belanja online yang mempromosikan dan menjual produknya. Namun, pencarian busana muslimah pada situs tersebut masih menggunakan teks, sehingga hasil pencarian produknya sering tidak sesuai dengan harapan konsumen.Pada penelitian ini, pencarian busana muslimah dilakukan dengan menggunakan isi visual citra atau disebut juga sebagai fitur, adapun fitur yang digunakan adalah kombinasi fitur warna dan bentuk, karena bentuk (model) dan warna merupakakan daya tarik bagi konsumen dalam memilih busana. Pencarian menggunakan isi gambar sebagai query dikenal dengan Content Based Image Retrieval (CBIR). Penelitian ini menerapkan Pyramid Histogram of Oriented Gradient (PHOG) sebagai metode ekstraksi fitur bentuk dan Dominant Color Descriptor (DCD) untuk ekstraksi fitur warna. Dataset yang digunakan ada 180 citra busana muslimah, terdiri dari 60 citra blus celana, 60 gamis, dan 60 outerwear. Kemiripan query dengan dataset dilakukan dengan menghitung jarak Euclidean. Pengukuran Kinerja CBIR busana muslimah menggunakan kombinasi fitur PHOG dan $D C D$ dilakukan dengan menghitung nilai recall, precision, dan $f$-measure. Hasil pengukuran kinerja menunjukkan bahwa kombinasi fitur PHOG dan DCD lebih baik diterapkan pada busana blus-celana. Berdasarkan pengukuruan kinerja dengan precision $(P)$, recall (RO, dan $f$-measure (F). Nilai tertinggi diperoleh dari kelompok busana berwarna merah sebesar 68 \% (P), 22.2\%, dan $33.3 \%$ (F). Kemudian diikuti dengan kelompok busana gamis, dan outerwear.
\end{abstract}

Kata Kunci - CBIR, PHOG, DCD, Fitur dan Busana.

\section{PENDAHULUAN}

Busana muslimah merupakan produk yang paling banyak dicari oleh konsumen terlebih pada saat bulan Ramadan dan menjelang lebaran. Konsumen mencari model-model busana muslimah terbaru yang sesuai dengan minatnya dan kemudian memutuskan untuk membeli busana tersebut. Biasanya pencarian busana muslimah dilakukan dengan memasukan kata kunci model dan warna busana yang diinginkan, namun pencarian sistem ini tidak efektif karena sulitnya mendeskripsikan model busana menggunakan teks sehingga busana muslimah yang ditemukan tidak seperti yang diharapkan konsumen. Oleh karena itu dibutuh sistem yang menggunakan isi gambar sebagai query (masukan) pencarian, sistem ini dikenal sebagai Content Based Image Retrieval (CBIR). CBIR bertujuan untuk menemukan cintra busana muslimah berdasarkan isi citra. Beberapa tahun belakang, busana muslimah merupakan objek penelitian yang sering digunakan pada CBIR [1]-[4]. Penelitian ini, menggunakan Deskriptor Warna Dominan (DWD) dan Deskriptor Korelogram Warna Dominan (DKWD) untuk ekstraksi fitur warna. Proses CBIR menggunakan DWD lebih cepat dan efektif karena jumlah warna yang dihasilkan lebih sedikit, namun 
tetap warna keseluruhan dari busana. Hasil penelitiannya menunjukkan DWD lebih baik dibandingkan dengan DKWD. Nilai rata-rata precision dan recall DKWD antara 0.7 sampai 0.9 , sedangkan DWD antara 0.7 sampai 0.8 [1].

Penelitian lainnya membandingkan kinerja Scalable Calor Descriptor (SCD) dan Dominan Color Descriptor (DCD), tiga kelompok busana yang digunakan yaitu biru, merah, dan coklat menunjukkan bahwa kinerja DCD lebih baik dibandingkan dengan SCD, karena DCD hanya mengambil warna dominan busana sebagai fiturnya. Dataset yang digunakan berjumlah 150 citra yang terdiri dari kelompok berwarna merah, hijau, biru, kuning, dan coklat. Masing-masing kelompok diwakili dengan 30 citra. Selain itu, penelitian ini juga menggunakan persepsi manusia dalam melihat warna dan efektivitas hasil temu kembali SCD dan DCD. Hasil simusi menunjukkan, kinerja DCD lebih baik dibandingkan dengan SCD. Kinerja SCD dan DCD diukur dengan f-measure, dari tiga kelompok warna yaitu merah, biru, dan coklat menunjukkan nillai f-measure untuk DCD lebih tinggi sebesar $10 \%$. Hasil penilaian dari perspektif 10 responden juga menunjukkan bahwa hasil temu kembali busana muslimah dengan DCD lebih baik dibandingkan dengan SCD[2]. Penelitian selanjutnya menerapkan metode Curvature Scale Space (CSS), busana muslimah dikelompokkan menjadi 3 yaitu, gamis, tunik, dan blus-celana. Metode CSS diterapkan pada 300 citra busana muslimah, masingmasing kelompok busana diwakili dengan 100 citra dengan panjang ciri CSS-nya 4. Hasil retrieval terbaik diperoleh dari kelompok busana blus-celana kemudian tunik dan selanjutnya gamis. Pengambilan panjang ciri CSS dapat mempengaruhi hasil retrieval. Semakin panjang ciri semakin rendah kinerja temu kembali, karena ciri yang panjang memuat puncakpuncak kecil dari peta kontur CSS yang merupakan derau [3]. Selain itu, retrieval busana muslimah telah dilakukan dengan metode Pyramid Histogram of Oriented Gradients (PHOG), pada penelitian ini jenis busana yang digunakan sebagai dataset yaitu blusrok, blus-celana, gamis, dan outerwear. Hasil penelitian menunjukkan jenis blus-celana memberikan retrieval terbaik [4].

Penelitian lainnya mengenai busana telah dilakukan dengan menerapkan klasifikasi citra Co nvolutional Neural Network (CNN) [5], algoritma yang diterapkan dalam penelitian tersebut dibuat untuk merekomendasikan produk yang cocok ( $m i x$ - and- macth) untuk setiap busana seperti jam tangan, tas, dasi, dan sepatu. selain itu, penelitian tersebut juga berhasil mengembangkan dataset baru produk-produk fashion dari toko online ( $e$ commerce).

\section{A. Content Based Image Retrieval (CBIR)}

Content Based Image Retrieval (CBIR) adalah sistem pengambilan gambar berdasarkan konten. CBIR mengambil atau menemukan kembali gambar (citra) dari basisdata citra (dataset) berdasarkan kemiripan visual. Pencarian citra menggunakan konten lebih baik dibandingkan dengan menggunakan teks [6]. Pada CBIR, citra dikategorikan menjadi dua yaitu citra query dan citra basisdata atau citra dataset. Citra query merupakan citra yang diinput untuk dicari kemiripannya, berdasarkan fitur dari objek dalam citra tersebut. Citra query dapat berasal dari dataset atau dari luar dataset. Citra Dataset merupakan kumpulan citra. Adapun fitur-fitur yang dapat digunakan yaitu fitur tekstur, warna, dan bentuk [7]. CBIR berjalan pada dua sisi yaitu sisi query (citra query) dan sisi basis data (citra dataset) dengan tahapan proses yaitu preprocessing, ekstraksi fitur, dan pencocokan fitur dengan menghitung jarak euclidean [8].

\section{B. Pyramid Histogram of Oriented Gradient (PHOG) \\ Pyramid Histogram of Oeriented Gradients} (PHOG) merupakan metode ekstraksi fitur bentuk dari sebuah citra. PHOG merepresentasikan spasial pyramid dari deskriptor Histogram of Oriented Gradient (HOG) atau gabungan dari fitur HOG[9].

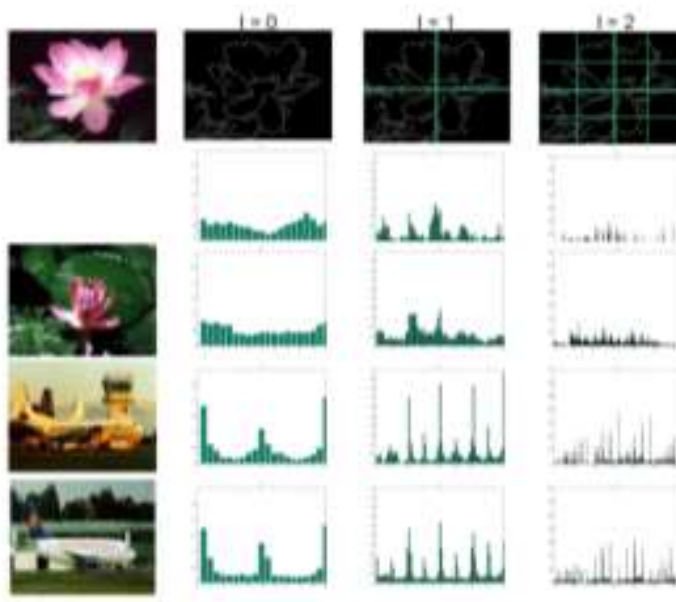

Gambar 1. Spasial Pyramid Citra [9]

C.

Metode ini, merepresentasikan citra ke dalam 3 level yaitu, level 0,1 , dan 2. Jumlah grid pada setiap level berbeda-beda. Jumlah grid ditentukan menggunakan persamaan $2^{2 l}$ (Level $l$ ) dan hitungan bin setiap level ditentukan menggunakan persamaan $K 2^{2 l}$ ( bin $\mathrm{K}$ ) [9]. 


\section{Dominant Color Descriptor (DCD)}

Warna adalah komponen utama dari gambar yang menarik penglihatan manusia. Fitur warna adalah salah satu fitur yang digunakan untuk retrieval gambar berdasarkan konten/isi gambar [10]. Dominan color deskriptor atau DCD adalah deskriptor yang dikembangkan oleh MPEG-7 untuk retrieval image. DCD menghasilkan fitur warna yang efisien, compact dan intuitif. Metode pengelompokan digunakan untuk mengekstrak warna. Warna dikelompokan menjadi 8 kelompok [11]. Fitur deskriptor warna ini menghasilkan 2 komponen utama: (1) Warna representatif, (2) persentase dari setiap warna. Dalam proses ekstraksi fitur warna dominan dapat dilakukan dengan langkah-langkah sebagai berikut: (1) urutkan persentase dari yang terbesar ke terkecil dari setiap warna, (2) persentase warna yang terbesar yang diambil sebagai warna dominan.

Persentase dari fitur warna tergantung dari ruang warna. Tidak semua ruang warna sesuai dengan persepsi mata manusia. Ruang warna yang digunakan dalam MPEG-7 yaitu familiar monochrome, RGB, HSV, YCrCb, HMMD dan transformasi linier matrik R, G, B. Ruang warna HSV lebih intuitif dan mendekati persepsi mata manusia.

\section{E. Pengukuran Kinerja CBIR}

Pengukuran kinerja CBIR dilakukan dengan menghitung nilai precision, recall, dan f-measure

1. Precision

Precision $(P)$ merupakan nilai perbandingan jumlah citra temu kembali yang relevan terhadap query dengan total jumlah citra yang terambil (retrieve) dalam proses CBIR [12]. Persamaan precision dapat dilihat pada persamaan (1).

$$
P=\frac{\text { Jumlah citra retrieve yang relevan }}{\text { Total jumlah citra retrieve }}
$$

\section{Recall}

Recall $(R)$ merupakan nilai perbandingan jumlah citra relevan yang terambil terhadap query dengan keseluruhan citra dataset yang relevan dengan query dalam proses CBIR [12]. Persamaan recall dapat dilihat pada persamaan (2).

$$
R=\frac{\text { Jumlah citra retrieve yang relevan }}{\text { Total jumlah citra relevan dalam database }}
$$

\section{F-measure}

$F$-measure $(F)$ merupakan nilai yang mewakili semua kinerja CBIR, $F$ - measure dapat dihitung dengan mengkombinasikan nilai recall $(\mathrm{R})$ dan precision ( $\mathrm{P} 0$ [12]. Persamaan f-measure dapat dilihat pada persamaan (3).

$$
F=\frac{2 P R}{P+R}
$$

\section{METODE PENELITIAN}

1. Skema Alur Penelitian

Tahapan-tahapan yang diterapkan dalam penelitian ini, pertama malakukan studi literature, pengumpulan citra, perancangan sistem CBIR Busana Muslimah menggunakan algoritma PHOG dan DCD kemudian simulasi, dan selanjutnya analisa dan evaluasi kinerja sistem. Pengukuran kinerja sistem CBIR dilakukan dengan menghitung nilai recall, precision, dan F-Measure. Tahap akhir dari penelitian ini yaitu menulis laporan penelitian.

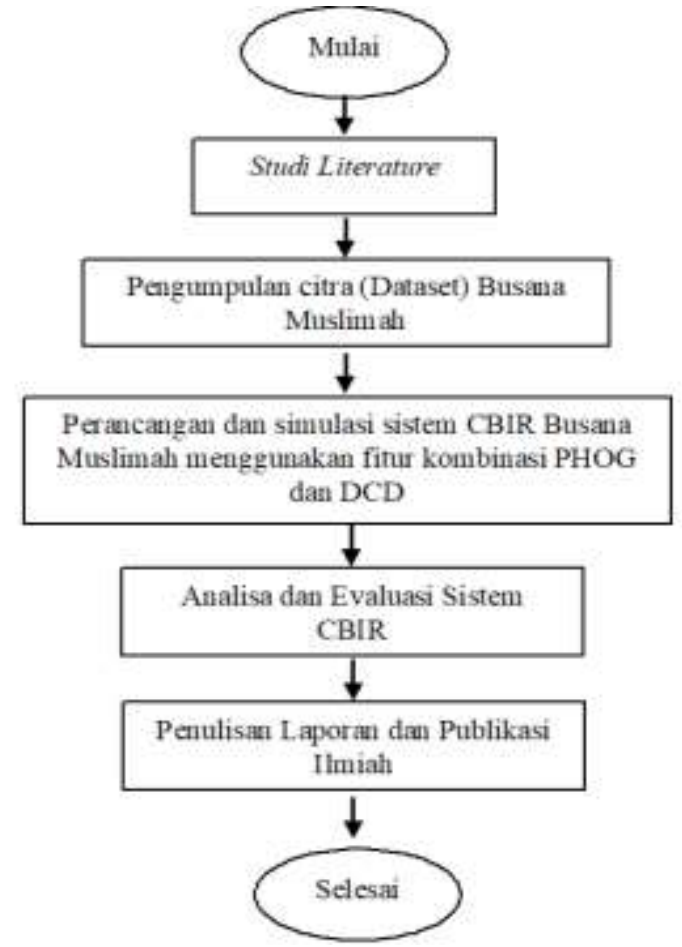

Gambar 2. Skema Alur Penelitian

Gambar.2 menunjukkan tahapan-tahapan yang dilakukan dalam penelitian ini: (1) Studi literatur Studi literatur dilakukan untuk mengetahui dan mempelajari objek yang akan diteliti secara lebih luas, dengan cara membaca buku atau jurnal penelitian ilmiah yang telah dilakukan dan membandingkan perbedaannya dengan penelitian yang akan dilakukan. (2) Pengumpulan Citra (Dataset) Merupakan tahapan pengumpulan citra busana muslimah yang dibutuhkan untuk melakukan pengujian dan testing sistem. (3) Perancangan dan Simulasi Sistem CBIR Merupakan tahapan perancangan user interface sistem CBIR dan algoritma ekstraksi fitur bentuk dan warna citra busana muslimah menggunakan PHOG dan DCD kemudian disimulasikan. (4) Analisa dan evaluasi sistem Setelah simulasi sistem CBIR dilakukan, tahapan selanjutnya adalah analisis hasil kinerja sistem CBIR menggunakan pengukuran Recall, Precision dan FMeasure. Jika hasil simulasi tidak memberikan hasil seperti yang diharapkan maka perlu dilakukan 
perbaikan-perbaikan terhadap sistem. (5) Penulisan Laporan dan publikasi naskah ilmiah.

\section{Pengumpulan Data}

Penelitian ini menggunakan citra busana muslimah sebagai data penelitian. Citra busana Muslimah dikelompokkan menjadi 3 yang terdiri dari gamis, outerwear, dan blus-celana dan dikelompokkan menjadi dua warna yaitu, merah dan navy. Setiap jenis busana terdiri dari 30 citra berwarna merah dan 30 citra berwarna navy. Dengan demikian total citra dataset pada penelitian ini adalah 180 citra. Citra dataset busana muslimah tersebut bersumber dari website saqina (www.saqina.com), hijabenka (www.hijabenka.com) dan juga pengambilan photo di Toko Busana Muslimah Diana Gallery. Citra yang digunakan berukuran 136 x 212 piksel dengan background warna putih.
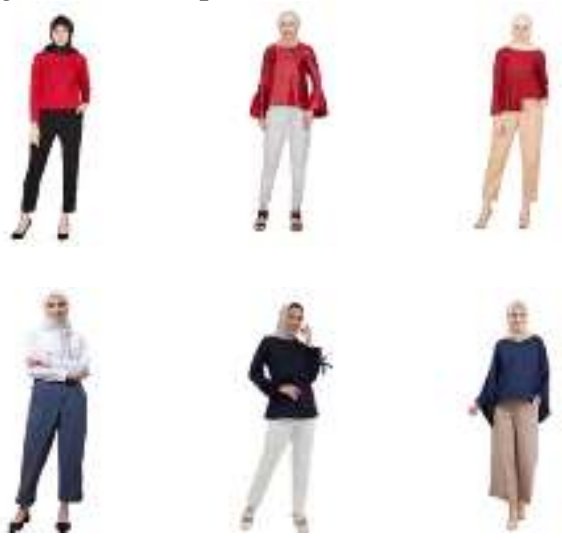

Gambar 3. Blus Celana
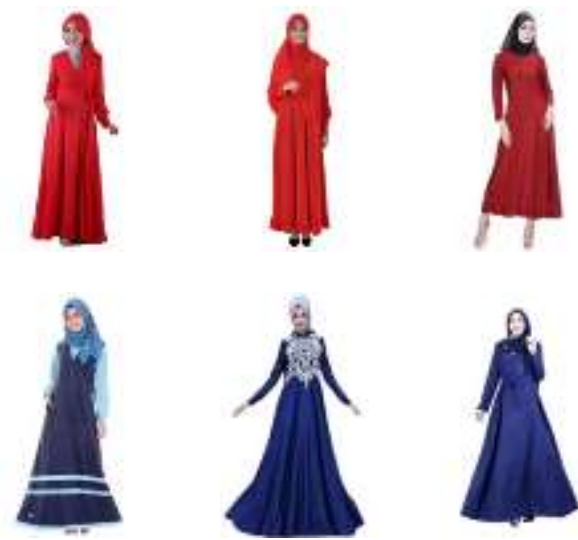

Gambar 4. Gamis
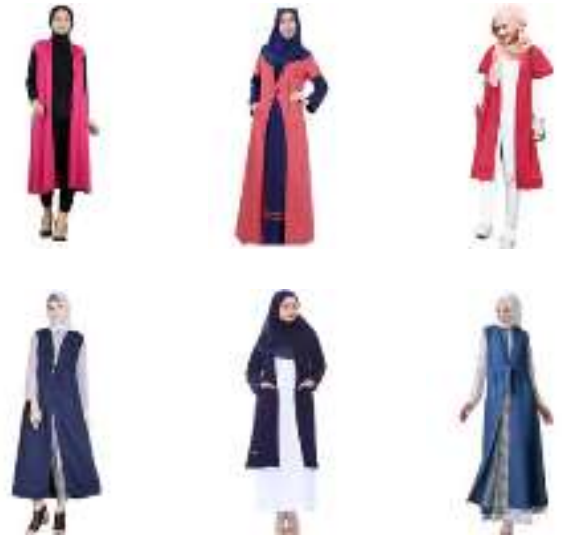

Gambar 5. Outerwear

3. Analisa Data

CBIR Citra Busana Muslimah yang dibangun dalam penelitian ini terdiri dari dua sisi, yaitu sisi query dan sisi database, dimana kedua sisi tersebut memiliki proses yang sama. Prsoses awal dimulai dari pre-processing, kemudian dilanjutkan dengan ekstraski fitur PHOG dan DCD, pengukuran kemiripan citra serta tahapan terakhirnya melakukan penilaian kinerja hasil retrieval aplikasi. Pengukuran kinerja diukur dengan recall, precision, dan f-measure. Alur CBIR busana muslimah dapat dilihat pada Gambar 6 .

a. Pre-Processing

Pre-processing merupakan tahapan awal CBIR busana muslimah. Pre-Processing adalah proses mempersiapkan citra agar dapat menghasilkan ciri yang lebih baik. Pada sistem CBIR busana muslimah menggunakan metode PHOG tahapan pre-processing yang dilakukan yaitu, konversi citra RGB. Sedangkan untuk metode DCD, pada tahap pre-processing cintra RGB (Red, Green, Blue) di konversikan ke ruang warna HSV (Hue, Saturation, Value).

b. Ekstraksi Fitur

Pada tahapan ini, dilakukan proses pengambilan ciri dari busana muslimah atau dikenal juga dengan istilah ekstraksi fitur. Metode yang digunakan yaitu pyramid Histogram of Oriented Gradient (PHOG) untuk mengektraksi fitur bentuk dan Dominant Color Descriptor (DCD) untuk ekstraksi fitur warna 


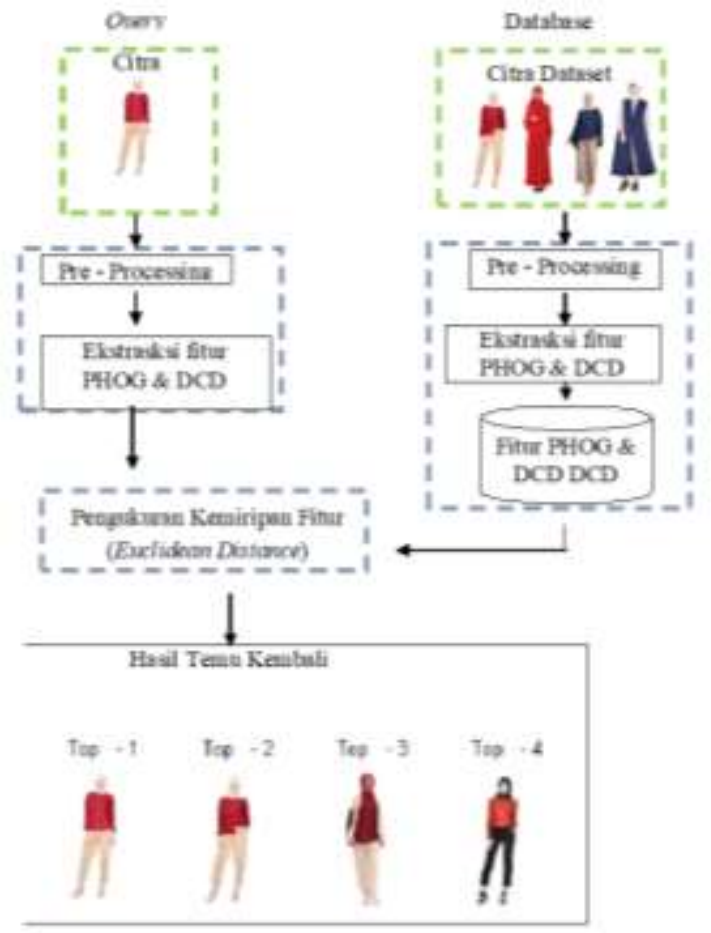

Gambar 6. Alur CBIR Busana Muslimah

c. Pengukuran Kemiripan Fitur

Setelah ekstraksi fitur dilakukan, selanjutnya akan dilakukan pengukran kemiripan fitur citra query dengan fitur citra dataset dengan menggunakan metode jarak euclidean (Euclidean Distance). Fitur citra query dan dataset direpresentasikan dalam bentuk vektor. Jarak Euclidean adalah satu metode yang sering digunakan untuk menghitung kesamaan antara dua vektor. Persamaan Euclidean dapat dilihat pada persaman (4).

$$
d_{X Y}=\sqrt{\sum_{i=1}^{n}\left(X_{i}-Y_{i}\right)^{2}}
$$

\section{Tahapan Ekstraksi Fitur PHOG}

Tahapan awal ekstraksi fitur phog dimulai dengan menghitung nilai gradien menggunakan kernel sobel dan kemudian menghitung arah gradien, selanjutnya matriks nilai arah gradien tersebut direpresentasikan ke dalam 3 level: (a) level 0, (b) level 1 dan dan level 2 . Level 0 , matriksnya terdiri dari satu grid, level 1 terbagi kedalam 4 grid dan di level 2 terdiri dari 16 grid. Untuk memperoleh fitur PHOG, setiap grid membangkitkan histogram arah gradien dengan jumlah binnya sebanyak 9 bin. Level 0 membangun 1 histogram, level 1 membangun 4 histogram dan level 2 membangun 16 histogram, histogram-histogram dari tiga level tersebut digabungkan sehingga totalnya adalah 21 histogram.
Hasil pengabungan histogram tersebut merupakan fitur PHOG. Representasi spasial pyramid PHOG ditunjukkan pada Gambar 7.

\section{Tahapan Ekstraksi Fitur DCD}

Proses ekstraksi fitur warna mengunakan DCD dimulai dengan mengkuantisasikan nilai ruang warna HSV. Kuantisasi dilakukan dengan membagikan ketiga komponen yaitu komponen Hue $(\mathrm{H})$ menjadi 8 interval, dan komponen Saturation (S) dan Value (V) masing-masing menjadi 3 interval. Proses kuantitasi menghasilkan 72 warna yang berbeda.

Level 1
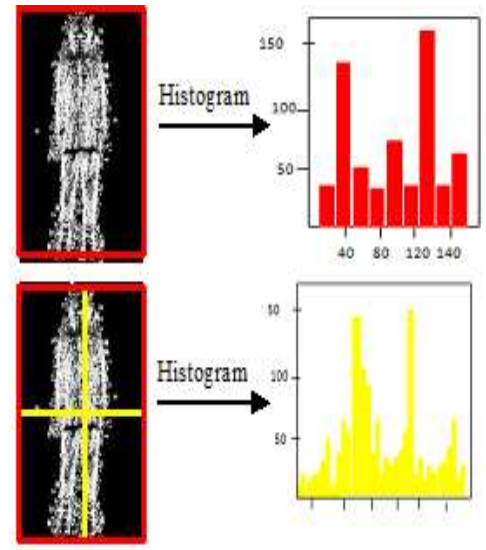

Level 2

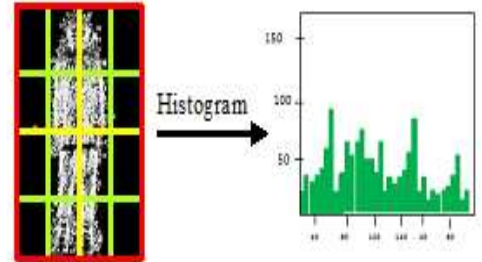

Fitur

PHOG

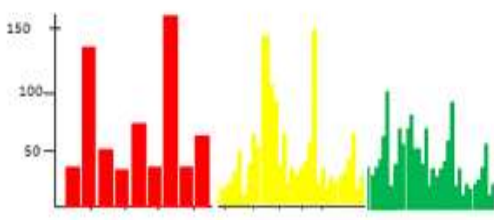

Gambar 7. Spasial Pyramid

\section{HASIL DAN PEMBAHASAN}

Content Based Image Retrieval Busana Muslimah berhasil diterapkan. Metode PHOG dan DCD dapat mengekrasi fitur bentuk dan warna dari 180 Citra Dataset yang terdiri dari kelompok blus-celana, gamis, dan outerwear, dan kemudian mengkombinasikan kedua fitur tersebut menjadi satu fitur vektor. Simulasi sistem CBIR menggunakan kombinasi fitur PHOG dan DCD dilakukan sebanyak 18 kali, masing- 
masin kelompok busana diwakili dengan 6 query, yaitu 3 query busana berwarna merah dan 3 berwarna navy yang dipilih secara acak. Gambar 8 menunjukkan hasil temu kembali busana dari query blus-celana, dari 10 citra hasil temu kembali, hanya 3 citra yang tidak relevan dengan query yaitu pada posisi 6,8 , dan 10 . Selanjutnya Gambar 9, menunjukkan hasil temu kembali dari query gamis. Hasil yang tidak relevan ada pada posisi 3, 4 dan 10. Posisi ke -3 , tidak relevan warna dan bentuk, posisi ke-4 tidak relevan warna, dan posisi ke-10 tidak relevan dengan bentuk.

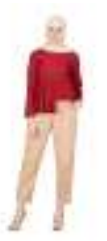

Query
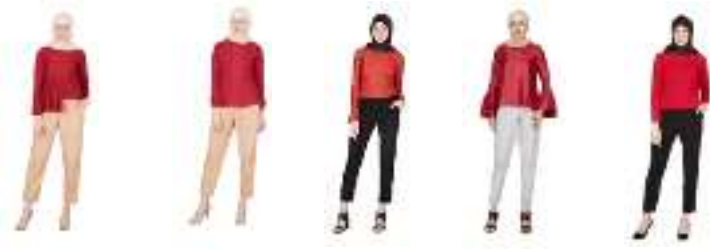

Top-1

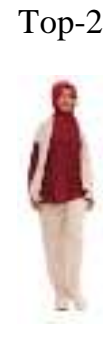

Top-7

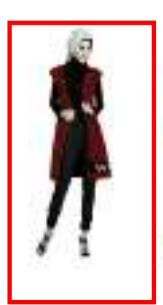

Top-4

Top-5

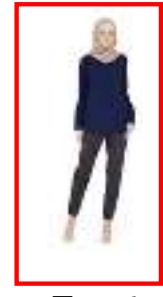

Top-6

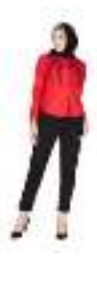

Top-9

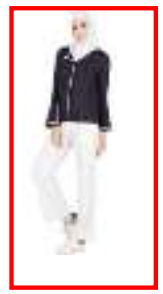

Top-10
Gambar 8. Hasil retrieve query blus-celana

Tabel 1.Blus Celana Merah

\begin{tabular}{|c|c|c|c|}
\hline $\begin{array}{c}\text { Jumlah } \\
\text { Temu } \\
\text { Kembali }\end{array}$ & $\mathrm{P}(\%)$ & $\mathrm{R}(\%)$ & $\mathrm{F}(\%)$ \\
\hline 10 & 67.67 & 22.22 & 33.33 \\
\hline 20 & 61.67 & 61.67 & 49.33 \\
\hline 30 & 48.89 & 48.89 & 48.89 \\
\hline
\end{tabular}

Tabel 2.Blus Celana Navy

\begin{tabular}{|c|c|c|c|}
\hline $\begin{array}{c}\text { Jumlah } \\
\text { Temu } \\
\text { Kembali }\end{array}$ & $\mathrm{P}(\%)$ & $\mathrm{R}(\%)$ & $\mathrm{F}(\%)$ \\
\hline 10 & 53.33 & 17.78 & 26.67 \\
\hline 20 & 48.33 & 32.22 & 38.67 \\
\hline 30 & 38.89 & 38.89 & 38.89 \\
\hline
\end{tabular}

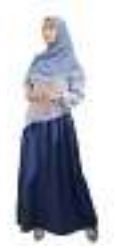

Query
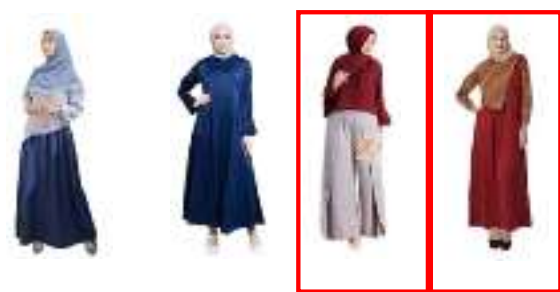

Top-2

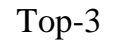

Top-4

Top-5
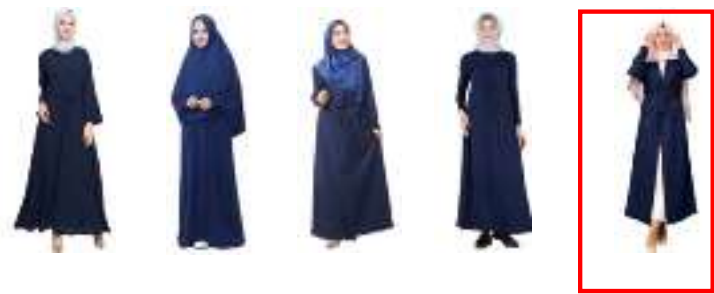

Top-6

Top-7

Top-8 Top-9

Top-10

Gambar 9. Hasil retrieve query gamis

Untuk melihat tingkat keberhasilan kinerja kombinasi fitur PHOG dan DCD, hasil temu kembali citra busana muslimah diukur menggunakan parameter recall, precision, dan $f$-measure. Hasil pengukurannya dapat dilihat pada Tabel.1, Tabel.2, Tabel.3, Tabel.4, Tabel.5 dan Tabel.6.

Tabel 3. Gamis Merah

\begin{tabular}{|c|c|c|c|}
\hline $\begin{array}{c}\text { Jumlah } \\
\text { Temu } \\
\text { Kembali }\end{array}$ & $\mathrm{P}(\%)$ & $\mathrm{R}(\%)$ & $\mathrm{F}(\%)$ \\
\hline 10 & 56.67 & 6.67 & 11.93 \\
\hline 20 & 50.00 & 11.76 & 19.05 \\
\hline 30 & 38.89 & 13.73 & 20.29 \\
\hline
\end{tabular}

\begin{tabular}{|c|c|c|c|}
\multicolumn{5}{|c}{ Tabel 4. Gamis Navy } \\
$\begin{array}{c}\text { Jumlah } \\
\text { Temu } \\
\text { Kembali }\end{array}$ & $\mathrm{P}(\%)$ & $\mathrm{R}(\%)$ & $\mathrm{F}(\%)$ \\
\hline 10 & 63.33 & 7.45 & 13.33 \\
\hline 20 & 56.67 & 13.33 & 21.59 \\
\hline 30 & 46.67 & 16.47 & 24.35 \\
\hline
\end{tabular}

\begin{tabular}{|c|c|c|c|}
\hline \multicolumn{4}{|c|}{ Tabel 5. Outerwere Merah } \\
\hline $\begin{array}{c}\text { Jumlah } \\
\text { Temu } \\
\text { Kembali }\end{array}$ & $\mathrm{P}(\%)$ & $\mathrm{R}(\%)$ & $\mathrm{F}(\%)$ \\
\hline 10 & 50.00 & 5.88 & 10.53 \\
\hline 20 & 36.67 & 8.63 & 13.97 \\
\hline 30 & 26.67 & 9.41 & 13.91 \\
\hline
\end{tabular}


Tabel 6. Outerwere Navy

\begin{tabular}{|c|c|c|c|}
\hline $\begin{array}{c}\text { Jumlah } \\
\text { Temu } \\
\text { Kembali }\end{array}$ & $\mathrm{P}(\%)$ & $\mathrm{R}(\%)$ & $\mathrm{F}(\%)$ \\
\hline 10 & 46.67 & 5.49 & 9.81 \\
\hline 20 & 40.00 & 9.41 & 15.24 \\
\hline 30 & 36.67 & 12.94 & 12.94 \\
\hline
\end{tabular}

Berdasarkan hasil perhitungan nilai precision, recall, dan $f$-measure yang ditunjukkan dalam tabeltabel di atas dapat dilihat bahwa kinerja kombinasi fitur PHOG dan DCD paling baik yaitu pada kelompok busana blus-celana dan paling rendah kelompok busana outerwere. Secara keseluruhan, rendahnya kinerja pada kelompok busana outerwere disebabkan karena bentuk busana outerwere memiliki kemiripan dengan gamis dan juga blus-celana. Sehingga, citra yang tidak relevan dengan query dalam hasil temu kembali query outerwere adalah citra gamis dan blus-celana.

\section{KESIMPULAN}

Penelitian ini berhasil menerapkan metode PHOG dan DCD untuk mengekstraksi fitur bentuk dan warna dari 270 dataset busana muslimah yang terrdiri dari 60 citra busana blus-celana, 60 citra gamis, dan 60 outerwere dan masing-masing dibagikan kedalam 30 warna merah dan 30 warna navy. Fitur yang digunakan dalam penelitisn ini, yaitu kombinasi fitur PHOG dan DCD. Hasil simulasi menunjukkan bahwa fitur ini cocok diterapkan pada busana blus-celana. Berdasarkan pengukuruan kinerja dengan precision, recall, dan $f$-measure, nilai tertinggi diperoleh dari kelompok busana berwarna merah sebesar $68 \%$ ( P), $22.2 \%$, dan $33.3 \%$ (F). Kemudian diikuti dengan kelompok busana gamis, dan outerwere.

\section{DAFTAR PUSTAKA}

[1] Y. Dhyanti, K. Munadi, and F. Arnia, "Penerapan Deskriptor Warna Dominan untuk Temu Kembali Citra Busana pada Peranti Bergerak," J. Rekayasa Elektr., vol. 12, no. 3, p. 104, 2016.

[2] A. F. Dewi, F. Arnia, and R. Muharar, "Effectiveness of MPEG-7 color features in clothing retrieval," Bull. Electr. Eng. Informatics, vol. 6, no. 2, pp. 166-173, 2017.

[3] H. Maghfirah, F. Arnia, and K. Munadi, "Temu Kembali Citra Busana Muslimah Berdasarkan Bentuk Menggunakan Curvature Scale Space (CSS)," J. Nas. Tek. Elektro dan Teknol. Inf., vol. 6, no. 1, pp. 7483, 2017.

[4] C. Mutia, F. Arnia, and R. Muharar,
"Improving the performance of CBIR on islamic women apparels using normalized PHOG," Bull. Electr. Eng. Informatics, vol. 6, no. 3, pp. 271-280, 2017.

[5] W. Zhou et al., "Fashion recommendations through cross-media information retrieval," J. Vis. Commun. Image Represent., vol. 61, pp. 112-120, 2019.

[6] O. N. Shpakov and G. V. Bogomolov, "Technogenic activity of man and local sources of environmental pollution," Stud. Environ. Sci., vol. 17, no. C, pp. 329-332, 1981.

[7] A.W. Rosyadi, R. Danardono, S.S. Manek and A. Z. Arifin, "A flexible sub-block in region based image retrieval based on transition region, vol. 11, no. 1, pp. 42-51, 2018.

[8] Y. Park, K. Park, and G. Kim, “Content-based image retrieval using colour and shape features," Int. J. Comput. Appl. Technol., vol. 48, no. 2, pp. 155-161, 2013.

[9] A. Bosch, A. Zisserman, and X. Munoz, "Representing shape with a spatial pyramid kernel," Proc. 6th ACM Int. Conf. Image Video Retrieval, CIVR 2007, pp. 401-408, 2007.

[10] H. Shao, Y. Wu, W. Cui, and J. Zhang, "Image retrieval based on MPEG-7 dominant color descriptor," Proc. 9th Int. Conf. Young Comput. Sci. ICYCS 2008, pp. 753-757, 2008.

[11] N. C. Yang, W. H. Chang, C. M. Kuo, and T. H. $\mathrm{Li}$, "A fast MPEG-7 dominant color extraction with new similarity measure for image retrieval," J. Vis. Commun. Image Represent., vol. 19, no. 2, pp. 92-105, 2008.

[12] N. V. Shirahatti and K. Barnard, "Evaluating image retrieval," Proc. - 2005 IEEE Comput. Soc. Conf. Comput. Vis. Pattern Recognition, CVPR 2005, vol. I, pp. 955-961, 2005. 